\title{
SOIL ATTRIBUTES AND BIOMASS YIELD FROM Pinus caribaea var. hondurensis
}

\author{
Robson Schaff Corrêa ${ }^{1}$, Antônio Francisco Jurado Bellote²
}

(received: January 28, 2010; accepted: February 25, 2011)

\begin{abstract}
Biomass yield from Pinus caribaea var. hondurensis is conditional on soil attributes. With the silvicultural practice currently being used in Brazil, Pinus stands might produce lower yields due to nutrient shift from harvest and due to changes in the edaphic environment from mechanization. Therefore, this study aims to evaluate chemical and physical soil attributes and determine which are correlated with higher biomass yields. Four commercial stands were selected, with differing growth patterns, each having four trees selected from the dominant layer, in addition to soil samples for chemical and physical analyses. Soil attributes and biomass yield data were submitted to analysis of variance (ANOVA), means were compared by the Tukey test, and the Pearson correlation coefficient was determined. Chemical attributes directly or indirectly associated with the sum of bases and physical attributes associated with water availability were found to be related to biomass yield.
\end{abstract}

Key words: Nutrition, growth, silviculture, fertility, soil physics.

\section{ATRIBUTOS DO SOLO E PRODUÇÃO DE BIOMASSA DE Pinus caribaea var. hondurensis}

RESUMO: A produção de biomassa de Pinus caribaea var. hondurensis é dependente dos atributos do solo. Com o modelo silvicultural atualmente adotado no Brasil, povoamentos de Pinus poderão diminuir a produção devido à exportação de nutrientes pela colheita e pela alteração do ambiente edáfico pela mecanização. Assim, avaliaram-se quais atributos químicos e físicos do solo estão relacionados a maiores produções de biomassa. Foram selecionados 4 plantios comerciais, com diferentes ritmos de crescimento, e selecionadas 4 árvores do extrato dominante, além de solo para as as análises químicas e físicas. Para a avaliação das diferenças entre os atributos do solo e de produção de biomassa foram aplicados análise de variância (ANOVA), teste de comparação de médias (Tukey) e determinado o coeficiente de correlação de Pearson. Os atributos químicos ligados direta ou indiretamente à soma de bases e os físicos ligados à disponibilidade hídrica apresentaram relação com a produção de biomassa.

Palavras-chave: Nutrição, crescimento, silvicultura, fertilidade, física do solo.

\section{INTRODUCTION}

The Brazilian forest-based industrial sector is one of the most competitive in the international scene, relying primarily on nonnative forests of species from genus Eucalyptus and Pinus for supply of raw material. In 2009, the total area planted with Pinus was around 1,795 thousand ha (ABRAF, 2010), consisting predominantly of subtropical species as opposed to tropical species.

Although fertilization practices are recommended in commercial forestry, Pinus stands usually do not receive such treatment. Reasons for that include good growth rates and absence of nutritional deficiency symptoms in species such as $P$. taeda and $P$. elliottii (REISSMANN; WISNIEWSKY, 2005). In some cases, however, the number of rotations, as in relation to $\mathrm{N}$, is now reaching threshold limits (BIZON, 2005), whether due to some stands dating back to the 50's (IPEF, 1976), or due to the presence of low fertility soils or shorter crop rotations. Works exploring nutrient deficiency in tropical species of Pinus are few and scarce in Brazil (CHAVES; CORRÊA, 2003).

Also, there is growing concern about hydrophysical restrictions in soils, which potentially reduce the effect intensity of their chemical properties on plant growth (BELLOTE; DEDECEK, 2006).

Typically, $P$. caribaea has excellent adaptability qualities even in environments differing from originating centers, yet some limits should not be exceeded (LIMA, 1990). It is thus necessary that research data be used in support of commercial forestry, combining knowledge of plant behavior with studies of the actual planting sites (CHAVES; CORRÊA, 2003). The idea is to determine what site factors contribute toward improved forest yields. The objective of this work is thus to define which physical and chemical soil attribute or attributes affect biomass yield in Pinus caribaea var. hondurensis stands.

${ }^{1}$ Forest Engineer, Ph.D. candidate in Forest Engineering - Laboratório de Ecologia Florestal - Centro de Ciências Rurais - Universidade Federal de Santa Maria - Avenida Roraima, 1000 - 97105-900 - Santa Maria, RS, Brasil - schaffcorrea@yahoo.com.br

${ }^{2}$ Agronomic Engineer, Ph.D. in Forest Science, Researcher - Embrapa Florestas - Estrada da Ribeira, km 111 - Cx. P. 319 - 83411-000 - Colombo, PR, Brasil - bellote@cnpf.embrapa.br 


\section{MATERIALS AND METHODS}

\subsection{Study site}

The material was collected in São Paulo state, at geographical coordinates $-22^{\circ} 20^{\prime}$ to $-22^{\circ} 29^{\prime}$ and $-48^{\circ} 51^{\prime}$ to $-48^{\circ} 59^{\prime}$. The local relief is predominantly flat and sits at an altitude of around $550 \mathrm{~m}$. Taxonomic soil units ${ }^{1}$ include typic dystrophic red Latosol (EMBRAPA, 2006) in sites 1, 2 and 3, and gleysolic orthic quartzarenic Neosol (EMBRAPA, 2006) in site 4, both soils being structurally deep and posing no physical obstruction to root growth at the time of collection.

The local climate is typically tropical with dry winters, Aw type according to Köppen classification (ROLIM et al., 2007), with annual average temperatures of $21.8^{\circ} \mathrm{C}$ and annual average precipitation of $1,341 \mathrm{~mm}$ (MIRANDA et al., 2010).

\subsection{Site and tree selection}

The species of choice was Pinus caribaea var. hondurensis, using seed originated stands in 1st rotation, and initial spacing of $2.7 \mathrm{~m} \mathrm{x} 1.85 \mathrm{~m}$.

Sites were selected for sample collection based on forest inventory data provided by Empresa Duratex S.A. and also on soil analyses by Cavaglieri (2005). Four sites (treatments) were selected having site indices of 20 to 26 and with tree age ranging from 10.5 to 12 years, as illustrated in Table 1. Four trees were selected per site from the dominant layer, to a total of 16 trees.

Table 1 - Characteristics of stands sampled.

Tabela 1 - Características dos povoamentos amostrados.

\begin{tabular}{ccccccccc}
\hline \multirow{2}{*}{ Site } & \multicolumn{3}{c}{ Stand } & \multicolumn{4}{c}{ Average tree } & Reference \\
\cline { 2 - 7 } & IMAcc & IS & G & DAP & H & Vcc & age \\
\hline 1 & 26.2 & 19.9 & 36.1 & 14.9 & 13.8 & 0.116 & 10.0 \\
2 & 29.8 & 20.3 & 39.3 & 17.4 & 17.3 & 0.197 & 11.3 \\
3 & 36.2 & 22.4 & 44.1 & 16.7 & 16.0 & 0.168 & 10.0 \\
4 & 47.8 & 25.9 & 48.6 & 17.3 & 18.6 & 0.209 & 9.6 \\
\hline
\end{tabular}

Note: IMAcc $=$ average annual increase with bark $\left(\mathrm{m}^{3}\right.$ ha $^{-1}$ year $\left.^{-1}\right)$; IS = site index; $\mathrm{G}=$ basal area $\left(\mathrm{m}^{2} \mathrm{ha}^{-1}\right) ; \mathrm{DAP}=$ diameter at breast height $(\mathrm{cm}) ; \mathrm{H}=$ height $(\mathrm{m}) ; \mathrm{Vcc}=$ volume with bark $\left(\mathrm{m}^{3}\right)$; Reference age $=$ age on which the characteristics being determined were based (years).

${ }^{1}$ Data provided by Duratex S.A. according to soil inventory compiled in areas of the estate.

\subsection{Tree and soil sampling and processing}

Trees were felled level with the ground and the crown was separated into the following sections: live branches, needle-shaped foliage and tip section - log portion above the 6-cm minimum diameter. The total fresh matter of branches and needles was measured with a dynamometer. Samples were dried in a forced air circulation oven at $60^{\circ} \mathrm{C}$, and biomass was then derived from the correlation of total fresh matter with dry matter of samples.

Barked disks around $5 \mathrm{~cm}$ in thickness were removed from each log at heights $0.1 \mathrm{~m}, 0.3 \mathrm{~m}, 1.3 \mathrm{~m}$ and then every 2 meters until the minimum 6-cm diameter mark was reached. The biomass of wood and bark was determined according to Silva (1996), who proposes biomass determination based on volumes and densities. The volume was obtained using the Smalian method (FINGER, 1992) and densities were obtained using the hydrostatic scale method (DURLO, 1991).

On account of trees differing in age, the effect of age on biomass yield was assessed using analysis of covariance and, as a result, the wood biomass was standardized for age 11 years, while the remaining tree sections remained unchanged.

Soil was sampled by excavating from where the crown of each tree projected on the ground, sampling at depth levels $0-5 \mathrm{~cm}, 5-10 \mathrm{~cm}, 10-20 \mathrm{~cm}$ and $20-30 \mathrm{~cm}$, then submitting samples for chemical and physical analyses according to EMBRAPA (1997).

\subsection{Statistical analyses}

Data related to chemical and physical soil attributes and to the biomass of each tree section were submitted to ANOVA using a completely randomized design, and means were compared by the Tukey test. Pearson correlations were tested between soil attributes and biomass results. All analyses were performed using statistical application MSTAT-C ${ }^{\circledR}$, at a 5\% error probability level.

\section{RESULTS AND DISCUSSION}

\subsection{Chemical soil analysis}

According to Monte Serrat et al. (2006), the chemical attributes characterize low fertility soils in all sites (Table 2). In some attributes site 4 proved more fertile, including $\mathrm{pH}$ and base saturation (V\%) in all layers being analyzed, and also $\mathrm{P}$ in the $0-5 \mathrm{~cm}$ and 5-10 cm layers, besides higher $\mathrm{Ca}^{++}, \mathrm{Mg}^{++}$and $\mathrm{K}^{+}$values in relation to the other sites. Basic cations were found to be determining factors for yield also with P. taeda (MORALES, 2007). 
Table 2 - Soil chemistry at different depth levels, in each site being assessed.

Tabela 2 - Química do solo em diferentes profundidades em cada sítio avaliado.

\begin{tabular}{|c|c|c|c|c|c|c|c|c|c|c|c|c|c|}
\hline \multirow{2}{*}{ Depth } & \multirow{2}{*}{ Site } & $\mathrm{pH}$ & MOS & $\mathrm{P}$ & $\mathrm{K}$ & $\mathrm{Ca}$ & $\mathrm{Mg}$ & $\mathrm{Al}$ & $\mathrm{H}+\mathrm{Al}$ & SB & $\mathrm{CTC}_{\mathrm{pH} 7}$ & V & $\mathrm{m}$ \\
\hline & & $\mathrm{CaCl}_{2}$ & $\mathrm{~g} \mathrm{dm}^{-3}$ & $\mathrm{mg} \mathrm{dm}{ }^{-3}$ & \multicolumn{7}{|c|}{$\mathrm{cmol}_{\mathrm{c}} \mathrm{dm}^{-3}$} & \multicolumn{2}{|c|}{$\%$} \\
\hline \multirow{4}{*}{$0-5$} & 1 & $3.5 b$ & 18.1ab & $3.2 \mathrm{~b}$ & $0.04 \mathrm{~b}$ & $0.2 b$ & $0.2 \mathrm{bc}$ & $1.4 \mathrm{~b}$ & 5.1ab & $0.47 b$ & $5.5 b$ & $8.6 b$ & $75.1 \mathrm{a}$ \\
\hline & 2 & $3.7 \mathrm{~b}$ & 19.3ab & $3.3 b$ & $0.05 b$ & $0.8 \mathrm{~b}$ & $0.1 \mathrm{c}$ & $1.8 \mathrm{ab}$ & $6.5 a$ & $0.97 b$ & $7.4 \mathrm{ab}$ & $13.1 \mathrm{~b}$ & $64.6 \mathrm{~b}$ \\
\hline & 3 & $3.4 \mathrm{~b}$ & $36.2 \mathrm{a}$ & 5.0ab & $0.04 \mathrm{~b}$ & $0.7 \mathrm{~b}$ & $0.7 \mathrm{~b}$ & $2.2 \mathrm{a}$ & $8.7 \mathrm{a}$ & $1.46 \mathrm{~b}$ & $10.2 \mathrm{a}$ & $15.5 b$ & $60.9 b$ \\
\hline & 4 & $5.6 \mathrm{a}$ & $12.6 \mathrm{~b}$ & $5.9 \mathrm{a}$ & $0.17 \mathrm{a}$ & $2.9 \mathrm{a}$ & $1.3 \mathrm{a}$ & $0.1 \mathrm{c}$ & $2.0 \mathrm{~b}$ & $4.36 \mathrm{a}$ & $6.4 \mathrm{ab}$ & $67.2 \mathrm{a}$ & $1.6 \mathrm{c}$ \\
\hline \multirow{4}{*}{$5-10$} & 1 & $3.7 b$ & 16.0 & 2.6ab & 0.03 & $0.2 \mathrm{~b}$ & $0.2 \mathrm{~b}$ & $1.4 \mathrm{~b}$ & $4.6 \mathrm{~b}$ & $0.38 \mathrm{~b}$ & $5.0 \mathrm{~b}$ & $7.6 \mathrm{~b}$ & $78.8 \mathrm{a}$ \\
\hline & 2 & $3.8 b$ & 16.6 & $1.2 \mathrm{~b}$ & 0.04 & $0.4 \mathrm{~b}$ & $0.3 b$ & $2.0 \mathrm{a}$ & $6.4 \mathrm{a}$ & $0.67 \mathrm{~b}$ & $7.1 \mathrm{a}$ & $9.4 \mathrm{~b}$ & $74.8 \mathrm{a}$ \\
\hline & 3 & $3.7 \mathrm{~b}$ & 17.9 & $4.0 \mathrm{a}$ & 0.04 & $0.5 b$ & $0.3 b$ & $1.6 \mathrm{ab}$ & $5.7 \mathrm{ab}$ & $0.90 \mathrm{~b}$ & 6.6ab & $13.3 b$ & $64.4 \mathrm{~b}$ \\
\hline & 4 & $5.8 \mathrm{a}$ & 10.7 & $4.8 \mathrm{a}$ & 0.17 & $2.6 \mathrm{a}$ & $1.1 \mathrm{a}$ & $0.1 \mathrm{c}$ & $1.9 \mathrm{c}$ & $3.91 \mathrm{a}$ & $5.8 \mathrm{ab}$ & $66.3^{\mathrm{a}}$ & $1.6 \mathrm{c}$ \\
\hline \multirow{4}{*}{$10-20$} & 1 & $3.8 b$ & 10.6 & 1.4 & 0.02 & $0.2 \mathrm{~b}$ & 0.3 & $1.1 \mathrm{~b}$ & $4.0 \mathrm{~b}$ & $0.50 \mathrm{~b}$ & $4.5 b$ & $11.1 b$ & $69.0 \mathrm{a}$ \\
\hline & 2 & $3.9 b$ & 13.9 & 2.9 & 0.03 & $0.5 b$ & 0.1 & $1.8 \mathrm{a}$ & $5.8 \mathrm{a}$ & $0.63 \mathrm{~b}$ & $6.4 \mathrm{a}$ & $9.9 \mathrm{~b}$ & 73.6a \\
\hline & 3 & $3.8 \mathrm{~b}$ & 10.2 & 2.2 & 0.02 & $0.3 b$ & 0.2 & $1.2 \mathrm{~b}$ & $4.6 \mathrm{~b}$ & $0.48 b$ & 5.1ab & $9.4 \mathrm{~b}$ & $72.2 \mathrm{a}$ \\
\hline & 4 & $5.4 \mathrm{a}$ & 9.2 & 2.7 & 0.18 & $2.6 \mathrm{a}$ & 1.1 & $0.1 \mathrm{c}$ & $2.1 \mathrm{c}$ & 3.87a & 6.0ab & 62.9a & $1.7 \mathrm{~b}$ \\
\hline \multirow{4}{*}{$20-30$} & 1 & $3.9 \mathrm{~b}$ & $7.2 \mathrm{~b}$ & 0.8 & $0.02 b$ & $0.3 b$ & $0.1 \mathrm{~b}$ & $0.9 b$ & $3.5 b$ & $0.46 \mathrm{~b}$ & 4.0 & $11.4 \mathrm{~b}$ & $68.4 \mathrm{a}$ \\
\hline & 2 & $4.0 \mathrm{~b}$ & 10.8a & 1.2 & $0.01 \mathrm{~b}$ & $0.4 \mathrm{~b}$ & $0.2 \mathrm{ab}$ & $1.6 \mathrm{a}$ & $4.8 \mathrm{a}$ & $0.59 \mathrm{~b}$ & 5.4 & $10.9 \mathrm{~b}$ & $72.8 \mathrm{a}$ \\
\hline & 3 & $4.0 \mathrm{~b}$ & $7.1 \mathrm{~b}$ & 1.0 & $0.02 b$ & $0.1 \mathrm{~b}$ & $0.6 \mathrm{ab}$ & $0.9 \mathrm{~b}$ & $3.6 \mathrm{~b}$ & $0.77 \mathrm{~b}$ & 4.3 & $17.4 \mathrm{~b}$ & 54.3a \\
\hline & 4 & $5.1 \mathrm{a}$ & 9.3ab & 2.6 & $0.11 \mathrm{a}$ & 2.3a & $0.9 \mathrm{a}$ & $0.1 \mathrm{c}$ & $2.3 \mathrm{c}$ & $3.30 \mathrm{a}$ & 5.6 & 56.7a & $4.4 \mathrm{~b}$ \\
\hline
\end{tabular}

Note: numbers 1 to 4 for site indicate yield increase for an individual tree; different letters for the same column and depth indicate statistical difference by the Tukey test at $5 \%$; no letters for the same column and depth indicate no significant statistical difference. MOS = soil organic matter; $\mathrm{SB}=$ sum of bases; $\mathrm{CTC}=$ cation exchange capacity; $\mathrm{V} \%$ = base saturation; $\mathrm{m} \%=\mathrm{Al}$ saturation .

Although P. caribaea is present in low fertility environments, fertilizer application does improve yield outcome (ALVARADO et al., 2006). Results found in this study for sites 1, 2 and 3, all layers being considered, were around $0.04 \mathrm{cmol}_{\mathrm{c}} \mathrm{K}^{+} \mathrm{dm}^{-3} ; 0.3 \mathrm{cmol}_{\mathrm{c}} \mathrm{Ca}^{++} \mathrm{dm}^{-3}$ and 0.3 cmol $\mathrm{Mg}_{\mathrm{c}}^{++} \mathrm{dm}^{-3}$, higher than values found in stands with needle yellowishness and tree death symptoms, namely $0.02 \mathrm{cmol}_{\mathrm{c}} \mathrm{K}^{+} \mathrm{dm}^{-3} ; 0.1 \mathrm{cmol}_{\mathrm{c}} \mathrm{Ca}^{++} \mathrm{dm}^{-3}$ and $0.0 \mathrm{cmol}_{c}$ $\mathrm{Mg}^{++} \mathrm{dm}^{-3}$ (CHAVES; CORRÊA, 2005), demonstrating the adaptability of the species to low fertility environments, given that a small increase in the above contents dictated absence of deficiency symptoms. Despite adaptable to poor fertility soils, soils with higher $\mathrm{pH}$ and $\mathrm{V} \%$ were characteristic in higher yielding sites for $P$. taeda, yet with a low correlation between chemical attributes and growth (DEDECEK et al., 2008).

\subsection{Physical soil analysis}

Physical attributes (Table 3) showed less differentiation among sites than chemical attributes.
Soil density remained unchanged among sites in all depth levels, noting that the highest value found $(1.6 \mathrm{~kg}$ $\mathrm{dm}^{-3}$ ) is lower than the critical soil density value which ranges between 1.7 and $1.8 \mathrm{~kg} \mathrm{dm}^{-3}$ for similar texture soils (REICHERT et al., 2003). Total porosity (PT) was around $50 \%$, which is the ideal value generally speaking (MACHADO; FAVARETTO, 2006), with around 60\% of macropores.

Soil moisture at time of collection (UMC) provided lower values than at permanent wilting point due to extensive drought prior to sample collection, and the site with greater biomass provided a lower value due to high water requirements. As regards water availability (AD), only in the first layer $(0-5 \mathrm{~cm})$ was there a statistical difference among sites, with site 4 showing the highest value and, despite no statistical difference for layers 5-10 $\mathrm{cm}$ and $10-20 \mathrm{~cm}$, again site 4 provided the highest value. It is clear that greater yield in site 4 was due to chemical and physical soil attributes. Surface layers have greater importance for nutrition, particularly in poor, excessively 
Table 3 - Soil physics at different depth levels, in each site being assessed.

Tabela 3 - Física de solo em diferentes profundidades em cada sítio avaliado.

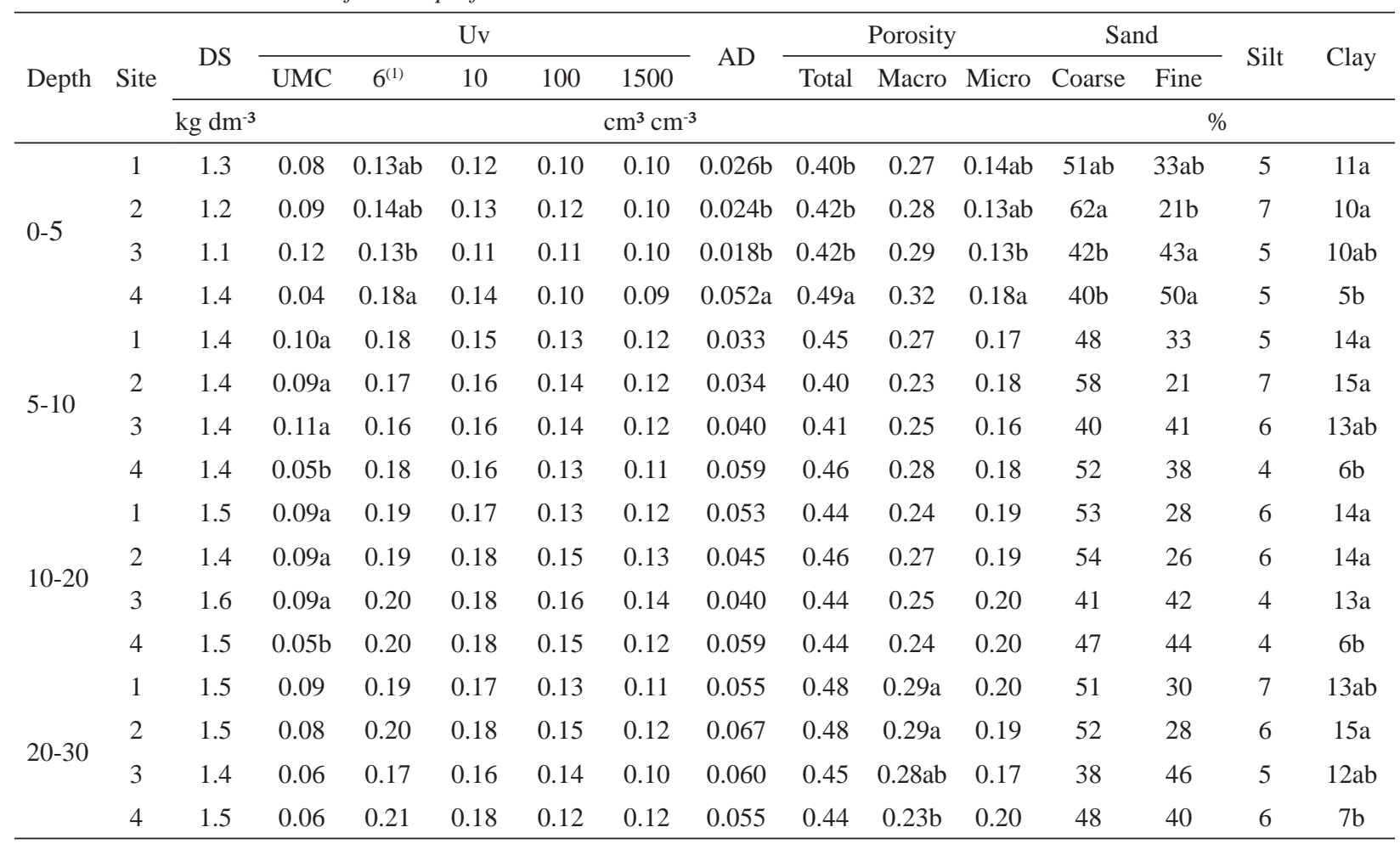

(1) tensions in $\mathrm{kPa}$.

Note: numbers 1 to 4 for site indicate yield increase for an individual tree; DS = soil density; Uv = Volumetric soil moisture; $\mathrm{UMC}=$ moisture at time of collection; $\mathrm{AD}$ = water availability; different letters for the same column and depth indicate statistical difference by the Tukey test at 5\%; no letters in the same column and depth indicate no significant statistical difference.

drained soils (REISSMANN; WISNIEWSKI, 2005), potentially stimulating growth. Clay content differed statistically among sites, with Neosol (site 4) not only showing the lowest content but also being the only soil falling into the 'sand' textural category, against the 'loamy sand' or 'sandy loam' textural categories of the other sites, all Latosols ${ }^{2}$ (Table 3).

\subsection{Biomass yield}

For the branch section, no difference was found among sites due to high variability in tree crowns within a single site (Figure 1). As regards the other tree sections, site 4 had the overall highest biomass, site 1 had the lowest biomass of wood and bark, and site 2 had the lowest needle biomass.

${ }^{2}$ Latosols with an average $18 \%$ of clay in the Bw subhorizons, reaching up to $29 \%$.

Cerne, Lavras, v. 17, n. 2, p. 181-187, abr./jun. 2011

\subsection{Correlation between soil attributes and biomass yield}

Chemical attributes relating to acidity $(\mathrm{H}+\mathrm{Al}, \mathrm{Al}$ and $\mathrm{m} \%$ ) influenced biomass yield negatively (Table 4). Although genus Pinus involves species tolerant of acidity and $\mathrm{Al}$, it is when these attributes are at low levels that species seem to grow more vigorously. A similar result was found by Dedecek et al. (2008).

Only for needle biomass at depths $5-10 \mathrm{~cm}$ and 20-30 cm ( $\mathrm{r}=0.58$ and $\mathrm{p}<5 \%$, data not provided) was a correlation found with the $\mathrm{P}$ content in the soil. Despite the higher content of this nutrient in the site with greater biomass, overall $\mathrm{P}$ availability in this study was considered low. This condition is naturally found in Brazilian cerrados and may have contributed to the outcome. This study is not to be considered conclusive, though, since Watanabe et al. (2009) found P to be a key factor for productivity. 


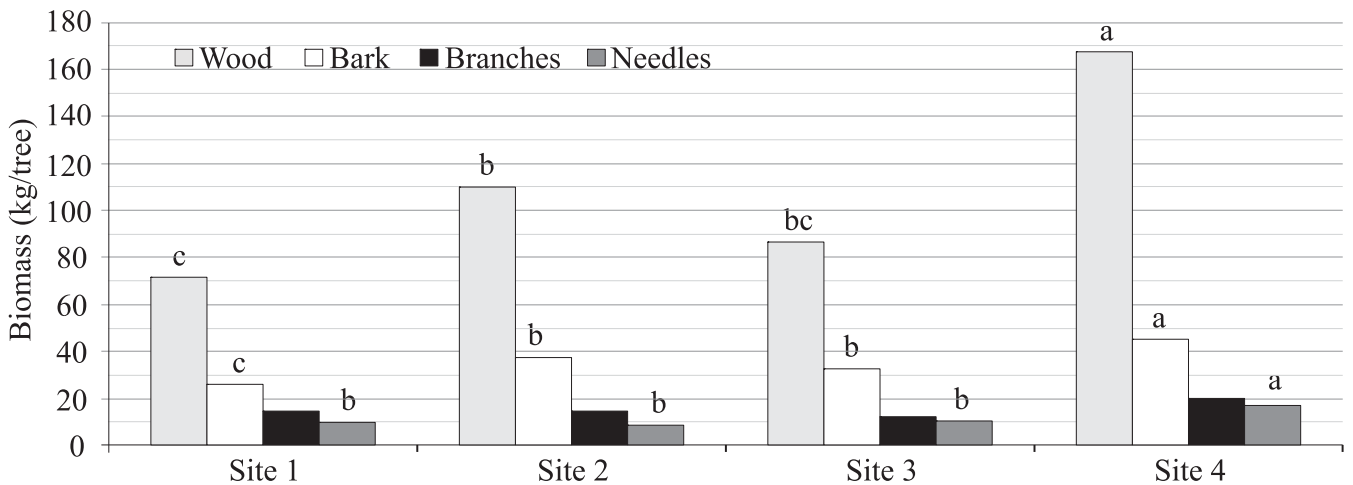

Note: numbers 1 to 4 for site indicate yield increase for an individual tree; different letters indicate statistical difference for a single tree section $(\mathrm{p}<0.05)$.

Figure 1 - Biomass in different tree sections of Pinus caribaea var. hondurensis.

Figura 1 - Biomassa em compartimentos de árvores de Pinus caribaea var. hondurensis.

Table 4 - Correlations above 0.70 ( $\mathrm{p}<=5 \%$ ) of physical and chemical soil attributes with biomass of Pinus caribaea var. hondurensis. Tabela 4-Correlações acima de 0,70 ( $p<=5 \%)$ entre atributos físicos e químicos do solo e biomassa de Pinus caribaea var. hondurensis.

\begin{tabular}{|c|c|c|c|c|c|c|c|c|c|c|c|c|}
\hline \multirow{4}{*}{ Attribute } & \multicolumn{12}{|c|}{ Depth } \\
\hline & \multicolumn{3}{|c|}{$0-5$} & \multicolumn{3}{|c|}{$5-10$} & \multicolumn{3}{|c|}{$10-20$} & \multicolumn{3}{|c|}{$20-30$} \\
\hline & \multicolumn{12}{|c|}{ Section } \\
\hline & $\mathrm{M}$ & $\mathrm{C}$ & A & $\mathrm{M}$ & $\mathrm{C}$ & A & M & $\mathrm{C}$ & A & $\mathrm{M}$ & $\mathrm{C}$ & $\mathrm{A}$ \\
\hline $\mathrm{pH}_{\mathrm{CaCl} 2}$ & 0.88 & 0.79 & 0.77 & 0.89 & 0.81 & 0.76 & 0.88 & 0.78 & 0.72 & 0.90 & 0.79 & 0.73 \\
\hline $\mathrm{K}^{+}$ & & 0.73 & & & & & & & & 0.72 & 0.72 & \\
\hline $\mathrm{Ca}^{++}$ & 0.89 & 0.88 & & 0.90 & 0.82 & & 0.87 & 0.84 & & 0.80 & 0.76 & \\
\hline $\mathrm{Mg}^{++}$ & & & & 0.79 & 0.76 & 0.74 & & & & & & \\
\hline $\mathrm{Ca}+\mathrm{Mg}$ & 0.88 & 0.84 & & 0.90 & 0.83 & 0.72 & 0.80 & 0.78 & & 0.80 & 0.78 & \\
\hline $\mathrm{Al}^{+++}$ & -0.72 & & & -0.71 & & -0.78 & & & -0.77 & & & -0.77 \\
\hline $\mathrm{H}+\mathrm{Al}$ & & & & & & -0.74 & & & -0.72 & & & -0.74 \\
\hline SB & 0.87 & 0.85 & & 0.88 & 0.83 & 0.71 & 0.79 & 0.78 & & 0.80 & 0.78 & \\
\hline $\mathrm{CTC}_{\mathrm{pH} 7}$ & & & & & & & & & & & 0.73 & \\
\hline $\mathrm{CTC}_{\mathrm{ef}}$ & 0.71 & 0.76 & & 0.85 & 0.86 & & 0.73 & 0.81 & & 0.76 & 0.81 & \\
\hline V\% & 0.88 & 0.83 & 0.74 & 0.89 & 0.81 & 0.79 & 0.87 & 0.77 & 0.74 & 0.83 & 0.77 & \\
\hline $\mathrm{Al} \%$ & -0.89 & -0.83 & -0.77 & -0.89 & -0.79 & -0.82 & -0.85 & -0.71 & -0.82 & -0.78 & -0.70 & -0.72 \\
\hline $\mathrm{Na}^{+}$ & & 0.76 & & & & & 0.72 & 0.81 & & 0.72 & & \\
\hline UMC & & & & -0.74 & & & -0.79 & & -0.82 & & & -0.74 \\
\hline PT & 0.76 & & & & & & & & & & & \\
\hline $\mathrm{AD}$ & 0.76 & & & & & & & & & & & \\
\hline $\mathrm{AT}$ & & & 0.73 & & & & 0.76 & & 0.74 & & & 0.83 \\
\hline Clay & -0.70 & & & & & & -0.79 & & -0.79 & & & \\
\hline
\end{tabular}

Where: $\mathrm{M}$ = wood; $\mathrm{C}=$ bark; $\mathrm{A}$ = needles; $\mathrm{AT}=$ total sand; $\mathrm{UMC}=$ soil moisture at time of collection; $\mathrm{PT}=$ total porosity; $\mathrm{AD}=$ water availability; $\mathrm{CTC}$ = cation exchange capacity; $\mathrm{SB}=$ sum of bases; $\mathrm{V} \%$ = base saturation. 
As regards physical attributes, factors found to correlate with tree growth included PT, AD, UMC, total sand and clay. The correlation of growth with $\mathrm{AD}$ was expected because the region from which trees were collected has a seasonal climate and soils have low water retention due to the high percentage of sand, therefore the greater the amount of water available to plants in this soil, the more they will grow. Another attribute relating to soil water, UMC, correlates negatively with growth because where trees grow more they notably need more water in order to produce biomass, and also, greater needle biomass provides more surface for water evaporation.

Only total sand and clay contents (besides UMC) showed repetitiveness in correlations. The total sand fraction correlated positively with growth, while the clay fraction correlated negatively with growth, which is a result associated to chemical properties, since the sandiest soil proved more fertile and the sand fraction is inert and hardly contributes to water storage. Sandy soils also allowed improved growth for Tectona grandis in sites of west-central Brazil (SILVA et al., 2000).

PT was found to correlate with biomass yield, yet other attributes, including microporosity, were also expected to have this correlation due to their relation to water availability and to the statistical differences among sites (Table 3).

No correlation was found in this study of physical or chemical attributes with biomass of live branches, for any site or depth. No references are available in literature to demonstrate this relationship, but in studies about biomass estimation the lowest coefficients of correlation are derived for branches (ANDRADE; HAY, 2007; SILVA et al., 2004; MELLO; GONÇALVES, 2008); in addition, the branch biomass did not differ among sites.

\section{ACKNOWLEDGMENTS}

We wish to thank CNPq for granting the scholarship and Duratex S/A for allowing and supporting data collection.

\section{REFERENCES}

ALVARADO, A.; RAIGOSA, J.; OVIEDO, J. Nutricion y fertilizacion del pino caribeño (Pinus caribaea). Quito: INPOFOS, 2006. 12 p. (Informaciones Agronomicas, 62).

ANDRADE, B. S. de; HAY, J. D. V. Estimation of aerial biomass of Lychnophora ericoides (Mart.). Brazilian Archives Biology Technology, Curitiba, v. 50, n. 4, p. 687-694, 2007.

\section{ASSOCIAÇÃO BRASILEIRA DOS PRODUTORES DE FLORESTAS PLANTADAS. Anuário estatístico da ABRAF 2010: ano base 2009. Brasília, 2010. 140 p.}

BELLOTE, A. F. J.; DEDECEK, R. A. Atributos físicos e químicos do solo e suas relações com o crescimento e a produtividade do Pinus taeda. Boletim de Pesquisa Florestal, Colombo, n. 53, p. 21-38, 2006.

BIZON, J. M. C. Avaliação da sustentabilidade nutricional de plantios de Pinus taeda $\mathrm{L}$. usando um balanço de entrada-saída de nutrientes. 2005. 95 f. Dissertação (Mestrado em Recursos Florestais) - Escola Superior de Agricultura Luiz de Queiroz, Piracicaba, 2005.

\section{CAVAGLIERI, V. S. Avaliação e correlação do status} nutricional de povoamentos de Pinus caribaea var. hondurensis com a produtividade e atributos do solo na Duratex. 2005. 44 p. Monografia (Graduação em Engenharia Florestal) - Escola Superior de Agricultura Luiz de Queiroz, Piracicaba, 2005.

CHAVES, R. de Q.; CORRÊA, G. F. Macronutrientes no sistema solo-Pinus caribaea Morelet em plantios apresentando amarelecimento das acículas e morte de plantas. Revista Árvore, Viçosa, v. 29, n. 5, p. 691-700, 2005.

CHAVES, R. de Q.; CORRÊA, G. F. Micronutrientes no sistema solo-Pinus caribaea Morelet em plantios apresentando amarelecimento das acículas e morte de plantas. Revista Árvore, Viçosa, v. 27, n. 6, p. 769-778, 2003.

DEDECEK, R. A.; FIER, I. S. N.; SPELTZ, R.; LIMA, L. C. de S. Influência do sítio no desenvolvimento do Pinus taeda L. aos 22 anos: estado nutricional das plantas. Floresta, Curitiba, v. 38, n. 3, p. 507-516, 2008.

DURLO, M. A. Tecnologia da madeira: peso específico. Santa Maria: CEPEF/UFSM, 1991. 29 p. (Série técnica, 8).

EMPRESA BRASILEIRA DE PESQUISA

AGROPECUÁRIA. Manual de métodos de análise de solos.

2. ed. Rio de Janeiro: CNPS, 1997. 212 p.

EMPRESA BRASILEIRA DE PESQUISA

AGROPECUÁRIA. Sistema brasileiro de classificação de solos. 2. ed. Rio de Janeiro: Embrapa Solos, 2006. 306 p.

FINGER, C. A. G. Fundamentos de biometria florestal. Santa Maria: UFSM, 1992. 269 p.

Cerne, Lavras, v. 17, n. 2, p. 181-187, abr./jun. 2011 
IPEF. Programa de melhoramento florestal da CAFMA. Piracicaba, 1976. (Circular técnica, 13). 7 p.

LIMA, R. T. Comportamento de espécies/procedências tropicais do gênero Pinus em Felixlândia-MG, Brasil, região de Cerrados: 1., Pinus caribaea var. hondurensis e Pinus oocarpa. Revista Árvore, Viçosa, v. 14, n. 1, p. 16-25, 1990.

MACHADO, M. A. M.; FAVARETTO, N. Atributos físicos do solo relacionados ao manejo e conservação de solos. In: LIMA, M. R. L. Diagnóstico e recomendações de manejo do solo: aspectos teóricos e metodológicos. Curitiba: UFPR, 2006. p. 233-254.

MELLO, S. L. de M.; GONCALVES, J. L. de M. Equações para estimar a biomassa da parte aérea e do sistema radicular em povoamentos de Eucalyptus grandis em sítios com produtividades distintas. Revista Árvore, Viçosa, v. 32, n. 1, p. 101-111, 2008.

MIRANDA, M. J. de; PINTO, H. S.; ZULLO JÚNIOR, J.; FAGUNDES, R. M.; FONSECHI, D. B.; CALVE, L.; PELLEGRINO, G. Q. Clima dos municípios paulistas: a classificação climática de Koeppen para o Estado de São Paulo. Disponível em: <http://www.cpa.unicamp.br/>. Acesso em: 30 out. 2010.

MONTE SERRAT, B.; KRIEGER, K. I.; MOTTA, A. C. V. Considerações sobre interpretações de análise de solo: com exemplos. In: LIMA, M. R. L. Diagnóstico e recomendações de manejo do solo: aspectos teóricos e metodológicos. Curitiba: UFPR, 2006. p. 125-142.

MORALES, C. A. S. Relação entre atributos do solo com a produtividade de Pinus taeda. 2007. 133 p. Dissertação (Mestrado) - Universidade para o Desenvolvimento do Estado de Santa Catarina, Lages, 2007.

REICHERT, J. M.; REINERT, D. J.; BRAIDA, J. A. Qualidade dos solos e sustentabilidade de sistemas agrícolas. Revista Ciência \& Ambiente, n. 27, p. 29-48, 2003.
REISSMANN, C. B.; WISNIEWSKI, C. Aspectos nutricionais de plantios de Pinus. In: GONÇALVES, J. L. M.; BENEDETTI, V. Nutrição e fertilização florestal. Piracicaba: IPEF, 2005. p. 135-166.

ROLIM, G. de S.; CAMARGO, M. B. P. de; LANIA, D. G.; MORAES, J. F. L. de. Classificação climática de Köppen e de Thornthwaite e sua aplicabilidade na determinação de zonas agroclimáticas para o Estado de São Paulo. Bragantia, Campinas, v. 66, n. 4, p. 711-720, 2007.

SILVA, D. J.; FERRAZ, J. B. S.; SANTOS FILHO, M. S.; SILVA, J. S. H. Avaliação do estado nutricional, crescimento de teca (Tectona grandis L.) e suas relações com os fatores de sítio do solo em plantios no sudoeste de Mato Grosso, a partir da análise de componentes principais. In: SIMPÓSIO SOBRE RECURSOS NATURAIS E SÓCIO-ECONÔMICOS DO PANTANAL: OS DESAFIOS DO NOVO MILÊNIO, 3., 2000, Corumbá. Anais... Corumbá, 2000. Disponível em: <http://www.cpap.embrapa.br/agencia/congresso/Bioticos>. Acesso em: 10 dez. 2006.

SILVA, H. D. da. Modelos matemáticos para a estimativa da biomassa e do conteúdo de nutrientes em plantações de Eucalyptus grandis Hill (ex- Maiden) em diferentes idades. 1996. 101 f. Tese (Doutorado em Ciências Florestais) Universidade Federal do Paraná, Curitiba, 1996.

SILVA, H. D. da; FERREIRA, C. A.; CORRÊA, R. S.; BELLOTE, A. F. J.; TUSSOLINI, E. L. Alocação de biomassa e ajuste de equações para estimativa de biomassa em compartimentos aéreos de Eucalyptus benthamii. Boletim de Pesquisa Florestal, Colombo, n. 49, p. 83-95, 2004.

WATANABE, Y.; MASUNAGA, T.; FASHOLA, O. O.; AGBOOLA, A.; OVIASUYI, P. K.; WAKATSUKI, T. Eucalyptus camaldulensis and Pinus caribaea growth in relation to soil physico-chemical properties in plantation forests in Northern Nigeria. Soil Science and Plant Nutrition, v. 55, n. 1, p. 132-141, 2009. 